\title{
WIDENING ACCESS TO UNIVERSITY ENGINEERING EDUCATION - AN INITIATIVE TO RAISE SCHOOL ATTAINMENT
}

\author{
Avril THOMSON, Andrew McLAREN and Richard ADAMS \\ University of Strathclyde
}

\begin{abstract}
This paper focusses on widening access to Engineering Education. Initially the context of widening access to Higher Education is presented together with the Scottish Government's target of ensuring that twenty percent of university students will come from Scotland's most deprived areas by 2030. An overview of widening access opportunities and support already in place in Scotland's universities is provided followed by a discussion of the particular challenges of Widening Access in Engineering Education. This paper then presents a description of a new initiative "Strathclyde Engineering Tutors in the Community" which aims to raise school attainment in school Maths and Physics through a one to one tutoring scheme. This initiative sees undergraduate students from different engineering disciplines supporting and tutoring school pupils from low progression schools as they prepare for their SQA examinations. Finally, the paper provides some reflections from initial findings of a pilot implementation of the initiative.
\end{abstract}

Keywords: Widening access, engineering, raising attainment, tutoring, mentoring

\section{INTRODUCTION}

SIMD 20 or SIMD $20 \%$ as it's sometimes referred to is the Scottish Index of Multiple Deprivation and it is a robust measure of area deprivation, based on a wide range of data, covering seven domains [1]. These seven aspects are income, employment, health, education, access to services, crime and housing [2]. The overall SIMD is a weighted sum of the 7 domains (aspects). There are 5.3 million people, 6976 data zones which equates to 760 people per zone.

In terms of access to education, statistics show that currently, where you are born and the area you grow up in conspire to make it much harder, for young people from Scotland's most deprived backgrounds. [3]. During a discussion on widening access to higher education a ministerial statement from the Scottish Minister for Further and Higher Education and Science, Shirley-Anne Somerville, that the government has accepted the ambitious targets to widen access. These targets are by 2030, $20 \%$ of all students entering University will be from Scotland's 20\% most deprived backgrounds.

In a recent study of the 15-24 Learner Journey [4] and the transition between School and University the review summarises that only $19.8 \%$ go onto HE from the most deprived areas in Scotland.

On top of this many of these pupils don't have the math and physics which are required by most Engineering degrees, this is making meeting the government targets a significant challenge.

The University of Strathclyde, Glasgow [5], Scotland has taken steps towards meeting this target though a pilot initiative. This pilot-initiated partners from four low progression schools located in the inner city of Glasgow and the Faculty of Engineering. This paper sets out to describe this initiative (which is still in its infancy).

\section{EXISTING APPROACHES TO WIDENING ACCESS}

An initial analysis was conducted to review the government publications [6], [7] and universities' widening access content as developed in their public facing websites [8]. The review criteria focused on the Scottish sector at undergraduate degree level and incorporated all study modes i.e. Full time and Sandwich courses. Part time study was not visible and therefore not included. Researchers focused on 
universities widening access strategy and guidance provided on their websites in the way of guidance for potential students.

The Scottish Government has decreed that all young people in Scotland must have the opportunity to attend university of their choice and have provided this support through the Scottish Funding Council (SFC) [3] provide much of the funding for universities to provide a widening access programme under the SHEP initiative (Schools for Higher Education Programme) [4]. An analysis was made on how Scotland's Universities classify individuals that are eligible for the Widening Access programme [10] [11]. It is important to stress that the information included in this study has been extracted from publicly available and therefore, may not provide a complete definition or overview of all the criteria available to individuals seeking assistance. All universities have WA contacts in place to respond to individual detailed questions that potential students.

\subsection{Widening Access Guidance}

The WA advice provided by universities via their websites varied considerably across Scotland which may be reflective geographical location and demographics. Not all universities highlighted or discussed SIMD 20 or 40 parameters, but all did refer to widening access. Universities located in the North did, however, have the most information about widening access. Aberdeen and RGU provided considerable information for prospective students [12] [13]. Their guidance descriptions were comprehensive and included many of the conditions necessary for university access.

When analysing the universities in the Central belt of Scotland the information provided was mixed in terms of volume from a reasonably well detailed description through to WAP mentioned in their webpages. The Glasgow and Edinburgh based universities [5] [14] [15] provided a comprehensive description of eligibility criteria. The Glasgow and Edinburgh based universities provided a consistent in-depth approach by highlighting the key conditions for WA that potential students could refer to. Which is consistent with the proximity and population size of these institutions.

For comparison a review was conducted of the top UK universities, in this case Oxford [17] and Cambridge [18], to determine if their widening access programmes were similar to Scottish universities. Whilst the focus is clearly on attaining the academic standard necessary to be admitted financial support is available via bursary systems

\subsection{Widening Access Programmes}

Table 1 captures a wide selection of the different types of Widening Access support currently provided by Scottish universities at the different stages of the student experience cycle. Some of this support is provided to potential students prior to and during application. Whilst other support is focused on supporting students once they are at university.

Table 1. Current Support and Programmes for Widening Access to

\begin{tabular}{|l|c|}
\hline Description of Top Up programmes supporting WAP & Stage Support is Offered \\
\hline $\begin{array}{l}\text { Contextualised offers for students from low progression } \\
\text { schools and SIMD 0-40 }\end{array}$ & application stage \\
\hline $\begin{array}{l}\text { Partnerships and pathway agreements with colleges i.e. the } \\
\text { Engineering Academy at the University of Strathclyde }\end{array}$ & application stage \\
\hline Access to university with a HNC or HND \\
\hline Sport connection for Widening Access & application stage \\
\hline School liaison focus on raising aspiration with S5/6 pupils & pre-application stage \\
\hline Mentoring with experienced students to share experience & after entry to university \\
\hline $\begin{array}{l}\text { Personal Academic Tutors through student support } \\
\text { programmes }\end{array}$ & pre-application stage \\
\hline $\begin{array}{l}\text { Top-Up programme - S5 and S6 pupils take part in 10 in- } \\
\text { school sessions }\end{array}$ & application stage \\
\hline $\begin{array}{l}\text { Online Summer School - help to upgrade qualifications for } \\
\text { uni entry }\end{array}$ & pre-application stage \\
\hline $\begin{array}{l}\text { Brightest Watts Outreach is a programme working with } \\
\text { pupils ranging from S1-S6. }\end{array}$ & application stage \\
\hline College connect a framework to progress from colleges into & \\
\hline
\end{tabular}




\begin{tabular}{|l|c|}
\hline university & \\
\hline $\begin{array}{l}\text { Caledonian Club a way of increasing awareness from early } \\
\text { learning to S6 in deprived areas }\end{array}$ & Pre-application stage \\
\hline $\begin{array}{l}\text { Focus West - funded by SFC delivered by staff and students } \\
\text { from universities \& colleges }\end{array}$ & Pre-application stage \\
\hline
\end{tabular}

Many initiatives focus on raising awareness of the opportunity and reality of university to school pupils who are likely be the first in their family to access Higher Education. Others focus on building confidence and skills. A wide variation of different access routes exist through college partnerships, access courses and summer schools etc. Contextualised offers provide pupils from low progression schools and Scotland's most deprived areas (SIMD 0-40) with the opportunity to access university with lower entry qualifications. Further initiatives offer additional support to students at university who gained access through a widening access route such as contextualised offer or further education partnership pathway.

\section{STRATHCLYDE ENGINEERING TUTORS IN THE COMMUNITY}

\subsection{Introduction}

Widening access to Engineering Education faces a unique set of challenges. The typical entry requirements for advanced school level qualifications in Physics and Mathematics presents a challenge for all. This is particularly problematic in low progression schools where often there is only one physics teacher in the entire school. This is further compounded by a general downward trend in the overall number of physics teachers across Scotland. There is evidence to suggest that contextualised offers whilst providing a viable access route for some SIMD 0-40 pupils can lead to a significant struggle in the early years of university for students entering through this pathway. Mathematics, and classes focusing on applied mathematics and physics such as mechanics, statics and fluid dynamics etc. can prove a particularly challenging to students who entered with slightly lower grades in Maths and Physics. Significantly, it is clear that pupils entering university through the contextualised offer route can lack confidence during the early stages of university. This section describes "Strathclyde Engineering Tutors in the Community" an initiative aimed to overcome these drawbacks.

\subsection{Strathclyde Engineering Tutors in the Community}

Strathclyde Engineering Tutors in the Community is an initiative in which senior students (years 3, 4 \& 5) from across the faculty of engineering provide weekly one to one maths and physics tuition to students in low progression schools. The aim being to raise attainment in these subjects giving pupils from low progression schools the opportunity to access Engineering Education without having to struggle with applied maths and physics classes in the early years of their study. The initiative was piloted in Oct 2018 working with two communities in Glasgow. Dennistoun/Bridgeton in the east end of Glasgow and Royston/Springburn in the North East of Glasgow. Four schools were selected to participate - two schools from within each of these communities - Springburn Academy and St Roch's Secondary School in the North East of the city. Whitehill Secondary and St Mungo's Academy in the east end of Glasgow. Schools were selected to participate in the pilot initiative based on low statistics of progression to higher education and specifically progression to study Engineering at Strathclyde. Proximity to the university was also a factor for the initial pilot. The university wanted to support pupils and schools on their doorstep who do not progress to engineering study. All of the participating schools are within a two-mile radius of the University. As well as supporting local communities this would facilitate travel for the tutors to the schools. Minimising travel time for tutors making weekly visits to the school.

12 tutors from across the faculty of engineering were selected to participate. This number was chosen as it would allow 3 students to be allocated to each of the 4 participating schools. Twelve was also felt to be a number that was manageable for a pilot initiative. An e-mail detailing the new initiative was distributed to senior students across three departments of the faculty of engineering. Students were offered the opportunity to 'sign-up' for a class associated with the initiative "STEM Engagement and Enhancement" for which they can gain 10 credits. In addition to this, students were offered $£ 200$ for engaging in a weekly one to one tutoring session within the school premises between November 2018 until the end of April 2019 when SQA examination study leave commenced. Class credits were 
offered to ensure that participating students continued with tuition sessions until the pupils were sitting their SQA examinations. Trust and reliability were identified as key factors in building confidence of the school pupils and in building a strong relationship between the pupils and the tutors. Over 40 students from across the faculty of engineering applied to participate in the initiative. Several criteria were used to select 12 students from the 40 applicants. Table 2 provides details of the selection criteria used.

Table 2. Criteria for selecting tutors

\begin{tabular}{|l|l|}
\hline \multicolumn{1}{|c|}{ Criteria } & \multicolumn{1}{c|}{ Rationale } \\
\hline personality & $\begin{array}{l}\text { It is essential for tutors to be personable, pupils who are relaxed } \\
\text { and have formed a relationship with their pupils will learn better }\end{array}$ \\
\hline previous experience of tutoring & $\begin{array}{l}\text { Experienced tutors are aware of the challenges and are more } \\
\text { likely to complete the initiative }\end{array}$ \\
\hline enthusiasm & Enthusiasm breeds passion, passion breeds success \\
\hline $\begin{array}{l}\text { proven ability in advanced } \\
\text { Mathematics and Physics }\end{array}$ & $\begin{array}{l}\text { Capability to deliver the required academic content with ease. It is } \\
\text { critical that these criteria is coupled with the right personality }\end{array}$ \\
\hline $\begin{array}{l}\text { Reside in proximity to partner } \\
\text { schools }\end{array}$ & $\begin{array}{l}\text { It is not desirable to have student tutors spending 2 hours } \\
\text { commuting to a school to deliver 1 hour of tuition. }\end{array}$ \\
\hline
\end{tabular}

The selection process involved review of a personal statement, academic record and a short face to face interview. All selected students were PVG checked and certified before commencing tutoring. The University consulted with each school to select 3 suitable pupils who would benefit most from one to one tuition. Pupils selected had to meet certain criteria - be sitting SQA examinations in Maths and Physics in 2019, have demonstrated ability and or interest in engineering or a technical discipline, be unable to access this type of service through any other means. Once pupils were selected "matching" of pupils with students' tutors took place where possible i.e. pupils with aspirations to study Mechanical engineering were matched with Mechanical Engineering students.

Initial meetings with each school were organised on a group basis. The three university students assigned to each school travelled together to the school and met their respective school pupils in a group setting. Where possible the university academic supervisor attended this meeting. The initial meeting was informal where pupils and students got the chance to chat to each other and discuss a suitable time to meet each week. Actual tutoring meetings started the week following the initial meeting and take place weekly in the school building during school term time. Tutoring meetings typically last one hour and generally take place at the end of the school day in a communal school area (library, street etc) although some tutors with sixth year pupils meet during free school periods. Meetings focus on help with homework, revisiting topics the pupil may be finding difficult, past papers, general advice and mentoring. Pupils from 2 of the participating schools have taken the opportunity to visit the university giving them first hand insight into facilities, resources and the chance to meet informally with students studying their course of interest.

\section{INITIAL REFLECTIONS}

Whilst Strathclyde Engineering Tutors in the community is still in its pilot phase having commenced in November 2018 there are several initial reflections that can be shared with others.

Pupils are benefitting from the initiative and value one to one interaction: quotes gathered from school pupils participating in the tutoring initiative suggest their experience is a positive one. Pupils specifically highlight the one to one aspect as being a key benefit.

"I have improved a lot in the class and understand things I never understood before" ... "The mentor programme is going really well, and I feel like it is helping me a lot in physics"... "Something I found really helpful was the one on one help. I am able to ask specific questions and focus on the things I really need help with"..."I think the tutoring has been really beneficial for me, it has given me a lot more confidence in myself"... "Helps with things I am struggling with one on one better than supported study"

Schools are requesting more tutors: Since the initiative commenced in January 20192 of the 4 schools have contacted the university coordinator asking if more tutors available to help additional pupils. This suggests the schools are seeing a positive impact from the initiative and value its input to their school community 
Visits to the university are valuable: Pupils and teachers found half day visits to the university an insightful experience. Giving pupils the opportunity to have a look around labs, classrooms and the general university campus facilities with the tutors they had built a relationship with was positive:

"helped me meet likeminded people who are doing the same course I am pursuing at university"

One lesson learned was that visits to the university could be timed to take place earlier in the school year before school pupils have completed their UCAS application forms. Pupils felt the experience of the visits would have helped them prepare better personal statements.

Tutors are gaining new skills: The tutors themselves are learning new skills and broadening their minds.

"Tutoring has taught me that everyone has a different way to learn best, and not everyone may

know what theirs is. It's really important to take the time to explore different methods and be creative to discover what best fits the individual and subject matter"

"Getting through to a pupil is not as easy as it would seem, but perseverance can achieve anything"

"I learned the ability to articulate mathematical processes in different ways and a better understanding of when to intervene"

Every school is different: The same information and guidance is given to each school, yet each school approaches the tutoring initiative slightly differently. Some schools selected pupils in their final year of school were able to identify pupils hoping to study specific engineering courses. Other schools chose pupils currently in their $4^{\text {th }}$ year of school who will be applying for university next year or the year after. Some schools prefer tutoring to take place in groups each week with all tutors arriving and leaving at the same time, others are happy for tutors to arrive and leave separately. Some schools prefer tutoring at the end of the school day, whist some were keen to encourage tutoring during pupil's free school periods.

Communication is a challenge: making contact with the right people within a school to establish this type of initiative can be challenging. The school environment relies heavily on face to face communication therefore many teachers do not check their email account regularly. Furthermore, it can be difficult to reach teachers or the school management by telephone as they are often teaching, in meetings or with parents or pupils. Communicating with schools requires patience and perseverance.

\section{REFERENCES}

[1] Government, Scottish. (2017, March). Commission on Widening Access - Technical paper on measures. Retrieved from

https://www.gov.scot/binaries/content/documents/govscot/publications/report/2016/03/blueprintfairness-final-report-commission-widening-access/documents/00496620-pdf/00496620pdf/govscot\%3Adocument

[2] Council, Scottish Funding. (2017, May 24). Chapter 3: Data and Measures - Scottish Funding Council. Retrieved from Scottish Funding Council: http://www.sfc.ac.uk/web/FILES/CMP_AccessandInclusionCommittee24May2016_24052016/A IC16_13_Annex_E_Chapter_3_Data_and_measures.pdf

[3] Government, Scottish. (2017, May). Minterial Statememnt. Retrieved from www.gov.scot: https://www.gov.scot/publications/widening-access-to-higher-education-ministerial-statement/

[4] Government, Scottish. (2018, March). Learner Journey: Analysis of Scottish education and training provision for 15 to 24 year olds. Retrieved from www.gov.scot: https://www.gov.scot/publications/learner-journey-analysis-scottish-education-trainingprovision-15-24-year/pages/6/

[5] Strathclyde, The University of. (2019, March 8). Widening access. Retrieved from www.Strath.ac.uk: https://www.strath.ac.uk/studywithus/wideningaccess/

[6] Access, Commissioner for Fair. (2017, December 13). Laying the Foundations for Fair Access Annual Report 2017. Retrieved from www.gov.scot: https://www.gov.scot/publications/layingfoundations-fair-access-annual-report-2017-commissioner-fair-access/

[7] Council, Scottish Funding. (2018, May 30). SFC Statistical publication report on Widening Access 2016-17. Retrieved from www.sfc.ac.uk: http://www.sfc.ac.uk/publicationsstatistics/statistical-publications/statistical-publications-2018/SFCST062018.aspx 
[8] WHATUNI. (2019, March 7). Engineering degrees in Scotland. Retrieved from www.whatuni.com: https://www.whatuni.com/degreecourses/search?subject=engineering\&location=scotland

[9] Trust, Sutton. (2016, May). ACCESS IN SCOTLAND Access to higher education for people from less advantaged backgrounds in Scotland. Retrieved from https://www.suttontrust.com/wpcontent/uploads/2016/05/Access-in-Scotland_May2016.pdf

[10] Scotland, Universities. (2019, March 7). Working to Widen Access. Retrieved from https://www.universities-scotland.ac.uk/wp-content/uploads/2017/11/Working-to-WidenAccess.pdf

[11] Universities, Scottish. (2019, March 7). The Voice of Scottish Universities. Retrieved from https://www.universities-scotland.ac.uk/

[12] University, Aberdeen. (2019, March 8). Widening Access. Retrieved from www.abdn.ac.uk: https://www.abdn.ac.uk/study/undergraduate/widening-access.php

[13] University, Robert Gordon. (2019, March 8). RGU continues to widen access by partnering with new school. Retrieved from www.rgu.ac.uk: https://www.rgu.ac.uk/news/news-2018/1444-rgucontinues-to-widen-access-by-partnering-with-new-school

[14] Glasgow University. (2019, March 8). WIDENING PARTICIPATION. Retrieved from www.gla.ac.uk: https://www.gla.ac.uk/study/wp/

[15] Glasgow Caledonia University. (2019, March 8). Widening Access. Retrieved from www.gcu.ac.uk: https://www.gcu.ac.uk/theuniversity/wideningaccess/

[16] University, Heriot Watt. (2019, March 8). Sudent Support. Retrieved from www.hw.ac.uk: https://www.hw.ac.uk/uk/student-support.htm

[17] Oxford University. (2019, March 8). Increasing access. Retrieved from www.ox.ac.uk: http://www.ox.ac.uk/admissions/undergraduate/increasing-access

[18] Cambridge University. (2019, March 8). Widening participation. Retrieved from www.undergraduate.study.cam.ac.uk: https://www.undergraduate.study.cam.ac.uk/find-outmore/widening-participation

[19] International, Hotcourses. (2019, March 7). On-campus Product Design. Retrieved from https://www.hotcoursesabroad.com/study/training-degrees/scotland/product-designcourses/loc/76/cgory/vf.2-4/sin/ct/programs.html 